\title{
PENGGUNAAN LIGHT EMITTING DIODE (LED) CELUP BAWAH AIR DENGAN WARNA BERBEDA: PENGARUHNYA TERHADAP HASIL TANGKAPAN BAGAN PERAHU
}

\author{
The Use of Underwater Light Emitting Diode (LED) With Different Color: Its Effect to The Catch Oo \\ Boat Lift Net \\ Oleh: \\ Hamidi $^{*}$, Mulyono Sumitro Baskoro², Mochammad Riyanto ${ }^{2}$ \\ ${ }^{1}$ Mahasiswa Program Studi Teknologi Perikanan Laut \\ ${ }^{2}$ Staf Pengajar Program Studi Teknologi Perikanan Laut \\ *Korespondensi: hamidi.ipb52@gmail.com
}

\begin{abstract}
ABSTRAK
Bagan perahu merupakan salah satu alat penangkap ikan yang dioperasikan pada malam hari. Alat tangkap ini menggunakan lampu sebagai attraktor untuk menarik ikan masuk kedalam area penangkapan. Lampu flourescent (neon) yang digunakan oleh nelayan bagan perahu di Perairan Aceh Barat Daya. Penelitian ini menggunakan lampu light emitting diode (LED) bawah air untuk meningkatkan hasil tangkapan. Namun efektivitas penggunaan lampu LED bawah air belum diketahui secara jelas. Tujuan penelitian ini adalah untuk menentukan pengaruh penggunaan lampu LED bawah air dengan warna yang berbeda terhadap hasil tangkapan bagan perahu. Ujicoba penangkapan ikan dilakukan pada bulan Agustus sampai September 2016 selama 12 hari dengan mengoperasikan bagan perahu menggunakan lampu LED (biru, merah dan kuning) dan lampu neon sebagai kontrol. Analisis data dilakukan dengan membandingkan total ikan hasil tangkapan antara lampu LED dan lampu neon. Berdasarkan hasil penelitian, total hasil tangkapan ikan dengan lampu LED biru dan merah adalah $38.38 \%$ dan $7.58 \%$, lebih besar dibandingkan bagan kontrol sebesar $23.61 \%$ dan $14.34 \%$. Sedangkan, total hasil tangkapan ikan LED kuning sebesar 4.04\%, lebih rendah dibandingkan bagan kontrol sebesar 12.05\%. Lampu LED biru menangkap tiga jenis ikan yaitu teri 37.92\%, kembung $49.17 \%$, dan tamban $44.5 \%$, berbeda secara nyata dibandingkan hasil tangkapan bagan kontrol $(\mathrm{P}<0.05)$.
\end{abstract}

Kata kunci: bagan perahu, hasil tangkapan, neon, LED.

\begin{abstract}
Boat lift net is one of the fishing gear which operate at the night. This fishing gear are using lamp to attract the fish. Fluorescent lamp is using in the lift net fishery in Aceh Barat Daya. This research is use the underwater light emitting diode (LED) in order to increase the catch. However, effectiveness of underwater LED lamps is still not yet known clearly. The objective is to determine the effect different colors of LED to the boat lift net catch. Experimental fishing was conducted in August to September 2016 for 12 days by operating boat lift net with underwater LED lamps (blue, red and yellow) with fluorescent lamp as a control. The data was analyzed by comparing the total catch between lift net LED lamps and fluorescent. The results showed, total catch of with underwater LED lamps of blue and red was $38.38 \%$ and $7.58 \%$, higher than the control as $23.61 \%$ and $14.34 \%$. While, total catch of yellow LED lamp as $4.04 \%$, was lower than the control as $12.05 \%$. The blue LED lamps were caught three species of Stelophorus devisi (37.92\%), Rastreliger kanagurta (49.17\%) and Dussumeieria elopssoides (44.50\%), which were significantly different to the lift net control $(P<0.05)$.
\end{abstract}

Keywords: boat lift net, catch, fluorescent lamp, LED. 


\section{PENDAHULUAN}

Bagan perahu merupakan salah satu alat tangkap nelayan di perairan Samudera Hindia, Provinsi Aceh. Sampai dengan tahun 2016 jumlah unit penangkapan menggunakan bagan perahu di perairan Aceh Barat Daya (ABDYA) mencapai 45 unit (DKP 2010). Secara umum bagan perahu yang digunakan nelayan dirancang khusus dengan menggunakan bahan-bahan yang sesuai untuk keperluan operasi penangkapan, seperti dua unit kapal bagan perahu, jaring angkat (lift net), rangka bagan (platform), lampu fluorescent dan mesin genset (Lestari 2000).

Operasi penangkapan bagan perahu di perairan ABDYA masih di minati oleh nelayan, hal ini disebabkan karena hasil tangkapan ikan yang masih banyak dan memiliki nilai jual yang cukup baik. Bagan perahu juga memiliki beberapa keunggulan secara teknis mudah di operasikan dengan biaya investasi terjangkau oleh masyarakat dan banyak menyerap tenaga kerja (Sudirman et al. 2011). Masyarakat nelayan bagan perahu di perairan ABDYA lebih memilih bekerja sebagai nelayan bagan perahu karena kegiatan penangkapan dilakukan pada malam hari, sehingga masyarakat nelayan memiliki waktu luang untuk melakukan aktivitas pekerjaan tambahan pada saat pagi hari. Penggunaan lampu flourescent pada saat operasi penangkapan nelayan bagan perahu belum maksimal dalam meningkatkan hasil tangkapan hal ini mengakibatkan kerugian waktu dan tenaga. Penggunaan mesin sebagai sumber arus listrik menggunakan bahan bakar minyak (BBM), sering mengalami kerusakan, hal ini mengakibatkan terhambatnya aktivitas penangkapan ikan dan mengakibatkan kerugian. Nelayan bagan perahu saat ini menggunakan lampu neon sebagai attraktor untuk memikat ikan. Penggunaan lampu ini memiliki kelemahan yaitu memerlukan energi listrik yang sangat besar dengan biaya operasional tinggi (Arif et al. 2015). Perkembangan teknologi berbasis LED memiliki keunggulan antara lain dapat memancarkan cahaya lebih terang dengan input energi yang kecil (Syafrie 2012). Lampu LED memerlukan arus searah (DC) sebagai sumber arus yang dapat di peroleh dari accu. Penggunaan accu ini memerlukan biaya operasional dan perawatan lebih mudah serta murah, di bandingkan dengan penggunaan lampu fluorescent yang menggunakan arus listrik dengan menggunakan mesin genset ataupun mesin diesel. Seiring perkembangannya penggunaan teknologi lampu LED pada penangkapan ikan saat ini, telah dikenalkan lampu LED bawah air yang dapat meningkatkan hasil tangkapan (Sulaiman 2010). Faktor cahaya menentukan keberhasilan operasi penangkapan pada bagan perahu (Simbolon et al. 2010). Pemasangan sumber cahaya (attractor) di atas jaring akan menarik ikan yang bersifat fototaksis positif sehingga akan berkumpul di area jaring (cathable area) (Ayodhyoa 1976 dan He et al. 1989).

Penelitian ini melakukan ujicoba inovasi lampu celup LED bawah air yang memiliki fungsi warna dapat diubah menggunakan kontrol LED sehingga memudahkan pada saat pengoperasian. Ujicoba penangkapan ikan menggunakan lampu celup LED bawah air, dibandingkan dengan lampu fluorescent sebagai kontrol untuk mengetahui jenis warna lampu yang efesien dalam meningkatkan hasil tangkapan. Penelitian ini bertujuan menentukan pengaruh penggunaan lampu LED bawah air dengan warna berbeda terhadap hasil tangkapan bagan perahu.

\section{METODE PENELITIAN}

Penelitian dilakukan selama bulan Agustus sampai September 2016. Pengambilan data dilaksanakan di perairan Aceh Barat Daya Provinsi Aceh yang termasuk kedalam Wilayah Pengelolaan Perikanan (WPP) 572. Data yang di ambil pada daerah penangkapan perairan Aceh Barat Daya yaitu berada pada 96o 79' 35” - 97o 09 '19” BT dan 3 66' 20” - 4o 05' 37’ LU. Peta lokasi penelitian disajikan pada Gambar 1. 


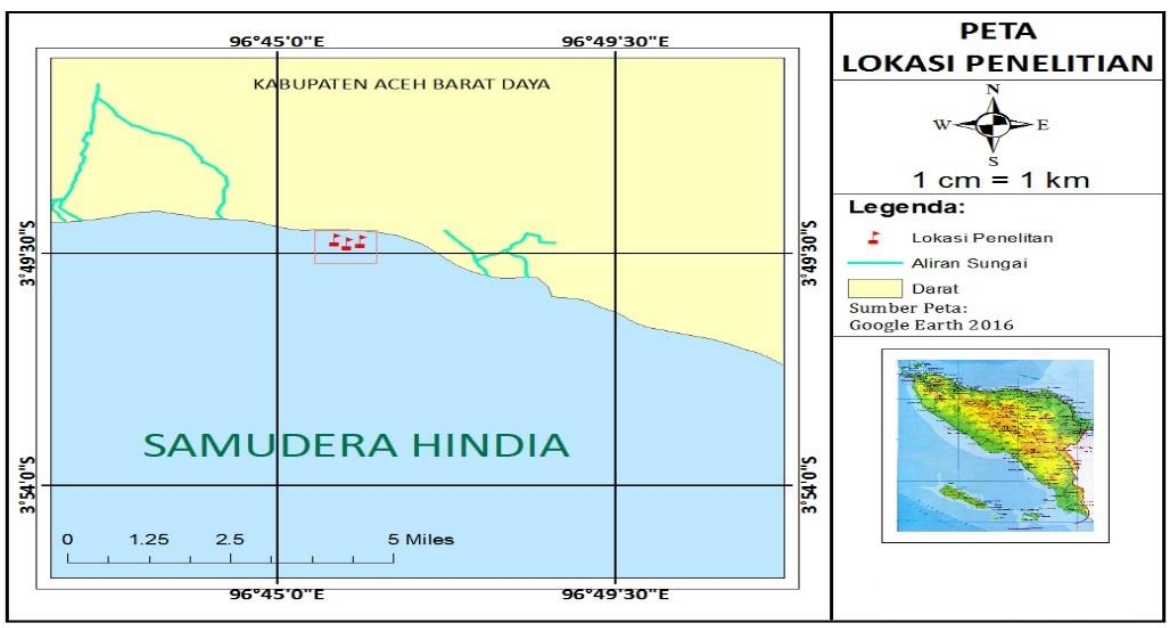

Gambar 1 Peta lokasi penelitian

Kontruksi bagan perahu yang digunakan pada penelitian ini adalah dua unit bagan perahu yang memiliki kontruksi sama di antara keduanya. Kapal bagan perahu berukuran panjang $13 \mathrm{~m}$ dengan lebar $1.5 \mathrm{~m}$ dan tinggi $1.8 \mathrm{~m}$ di tempatkan pada sisi kanan dan sisi kiri bagan perahu. Paltform bagan perahu berukuran panjang $10 \mathrm{~m}$ dan lebar $10 \mathrm{~m}$ serta di tambahkan sayap kayu pada setiap sudut depan dan belakang bagan perahu sebanyak 4 unit dengan ukuran panjang $15 \mathrm{~m}$ berfungsi untuk katrol tali jaring pada saat penurunan jaring (setting) dan pengangkatan jaring (hauling), jarak antara platform bagan perahu dari permukaan air $4 \mathrm{~m}$. Luas kerangka jaring $20 \mathrm{~m}$ dengan kedalaman pengoperasian jaring $25 \mathrm{~m}$. Bagan perahu pertama di pasang lampu uji coba model v.815 dengan warna lampu celup LED biru, merah dan kuning yang di tengelamkan ke dalam air pada posisi tengah platform bagan perahu dengan kapasitas daya sebesar 144 watt. Bagan perahu kedua kontrol menggunakan lampu neon nelayan sebanyak 135 unit dengan total daya sebesar 6.030 watt. Jenis lampu celup LED yang digunakan model v.815 berbentuk silinder dengan ukuran 15 x $20 \mathrm{~cm}$. Lampu berbentuk silinder memiliki keunggulan sebaran cahaya lebih merata saat dioperasikan pada perairan. Lampu celup LED ini tidak panas saat dioperasikan di dalam perairan. Serta memiliki daya tahan terhadap air, tidak panas saat di operasikan dalam air. Umur lampu yang digunakan cukup panjang sampai 50.000 jam atau 5 tahun masa penggunaan. Kontruksi lampu yang digunakan dapat di lihat pada Gambar 2.
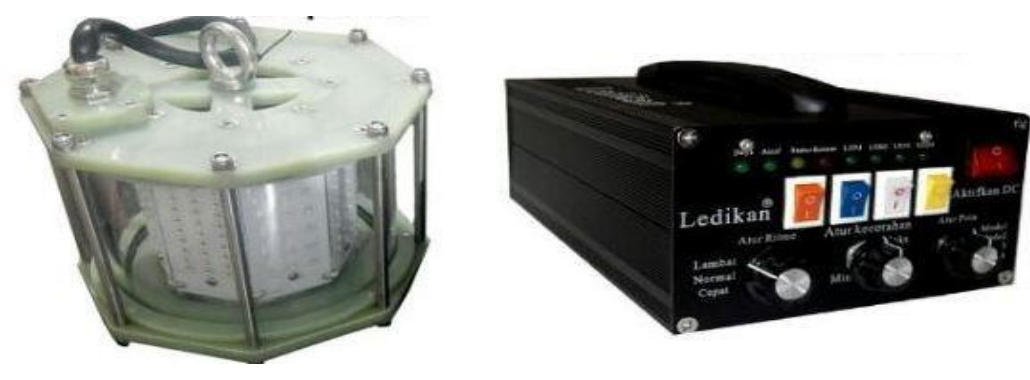

Gambar 2 Kontruksi lampu celup LED v.815

Lampu celup LED model v.815 telah menggunakan kontrol LED dilengkapi fitur tombol warna biru, merah dan kuning. Tombol atur ritme serta tombol atur kecerahan. Pengoperasian lampu celup ini menggunakan sumberdaya arus listrik dari baterai, dengan dihubungkan pada kontrol LED menggunakan kabel DC.

Metode penelitian yang digunakan dalam penelitian ini adalah experimental fishing. Pengumpulan data dilakukan dengan mengujicoba satu unit bagan perahu dengan menggunakan lampu 
celup LED bawah air sebagai bagan perlakuan dan satu unit bagan perahu dengan lampu neon sebagai kontrol. Jenis data yang dikumpulkan pada penelitian ini adalah komposisi hasil tangkapan berdasarkan warna lampu pada saat operasi penangkapan. Penelitian dilakukan selama 12 hari dengan pengoperasian empat hari pertama dilakukan ujicoba lampu celup LED biru kemudian empat hari berikutnya lampu celup LED merah dan empat hari terakhir lampu celup LED kuning. Ujicoba lampu celup LED dilakukan sebanyak 4 trip dengan 3 kali ulangan pertrip, sehingga total operasi penangkapan sebanyak 12 kali untuk setiap perlakuan. Pengoperasian dua unit bagan perahu di mulai dari jam 19.00:21.00, 21.00:00.00 sampai 00.00:04.45 WIB. Pengoperasian bagan perahu dilakukan pada satu kawasan perairan (fishing ground) yang sama dengan jarak 400-600 m antara bagan perahu perlakuan dan bagan kontrol. Selanjutnya hasil tangkapan bagan perahu dengan lampu celup LED bawah air dibandingkan dengan hasil tangkapan lampu fluorescent (neon) untuk mengetahui jenis lampu yang memberikan hasil tangkapan terbesar.

Data hasil tangkapan pada masing-masing perlakuan di analisis secara deskriptif comparative dengan membandingkan hasil tangkapan ikan pada bagan perlakuan dengan bagan kontrol. Data hasil tangkapan dijelaskan dengan menggunakan tabel dan grafik. Selanjutnya untuk melihat pengaruh terhadap hasil tangkapan dilakukan analisis sidik ragam rancangan acak lengkap (RAL) sebagai berikut, model linier: $Y i j=\mu+\tau i+\varepsilon i j$ dengan $Y i j=$ nilai respons pada perlakuan warna lampu celup LED ke-i dan ulangan ke- $j, \mu=$ rataan umum, $\tau i=$ pengaruh perlakuan warna lampu celup LED ke- $i, \varepsilon i j=$ pengaruh acak pada perlakuan lampu celup LED ke-i ulangan ke- $j, i=1 \ldots . t$ dan $j=1 \ldots . . r, r=$ ulangan dan $t=$ perlakuan. Asumsi yang digunakan adalah a.) komponen-komponen $\mu$, $\tau i$, dan $\varepsilon i j$ bersifat adifif, b.) nilai $\tau i$ tetap, $\Sigma \tau i=0, \mathrm{E}(\tau i)=\tau i$, c.) $\varepsilon i j \sim \mathrm{N}(0 . \sigma 2)$. Hipotesis pada penelitian ini adalah $H \sigma$. penggunakan lampu celup LED dengan warna yang berbeda tidak meningkatkan hasil tangkapan pada bagan perahu. $H_{1}$ : Penggunaan lampu celup LED dengan warna yang berbeda dapat meningkatkan hasil tangkapan pada bagan perahu. Analisis sidik ragam, penggolahan data analisis sidik ragam untuk mengetahui pengaruh penggunaan cahaya warna lampu celup LED dan neon terhadap hasil tangkapan menggunakan software SPSS. Keputusan, tolak $H_{0}$. nilai sig $<0.05$ artinya minimal ada satu penggunaan cahaya warna lampu celup LED yang berbeda nyata terhadap hasil tangkapan, terima Ho. nilai sig > 0.05 artinya tidak perbedaan nyata penggunaan cahaya warna lampu celup LED terhadap hasil tangkapan. Uji lanjut, uji lanjut Duncan digunakan untuk melihat perlakuan antara setiap perlakuan lampu celup LED apabila terdapat perbedaan yang paling berpengaruh terhadap hasil tangkapan.

\section{HASIL}

\section{LED biru}

Hasil tangkapan pada perlakuan lampu celup LED biru selama 12 kali operasi penangkapan mendapatkan total hasil tangkapan sebesar $1579 \mathrm{~kg}$ yang terdiri dari tiga spesies yaitu teri (Stolephorus devisi) sebanyak $445 \mathrm{~kg}$, kembung (Rastrelliger kanagurta) $590 \mathrm{~kg}$ dan tamban (Dussumieria elopsoides) $534 \mathrm{~kg}$. Sedangkan total tangkapan bagan kontrol sebesar $576 \mathrm{~kg}$ terdiri dari 3 spesies tiga spesies yaitu teri sebanyak $171 \mathrm{~kg}$, kembung $209 \mathrm{~kg}$ dan tamban $196 \mathrm{~kg}$. Komposisi total hasil tangkapan lampu celup LED biru dan bagan kontrol disajikan pada Gambar 3.

Total hasil tangkapan bagan perahu dengan lampu celup LED biru yaitu teri sebesar $37.92 \pm 4.99$ $\mathrm{kg}$, kembung $49.17 \pm 5.32 \mathrm{~kg}$ dan tamban $44.5 \pm 8.95 \mathrm{~kg}$. Sedangkan hasil tangkapan bagan kontrol teri sebesar $14.25 \pm 2.62 \mathrm{~kg}$, kembung $17.42 \pm 1.98 \mathrm{~kg}$ dan tamban $16.33 \pm 2.43 \mathrm{~kg}$. Berdasarkan hasil analisis statistik terdapat perbedaan yang nyata $(P<0.05)$ pada setiap hasil tangkapan lampu celup LED biru teri, kembung dan tamban dibandingkan hasil tangkapan bagan kontrol. Komposisi hasil tangkapan bagan perahu dengan lampu LED biru dan bagan kontrol disajikan pada Gambar 4. 


\begin{tabular}{|c|c|c|c|c|c|c|c|c|c|c|c|c|}
\hline 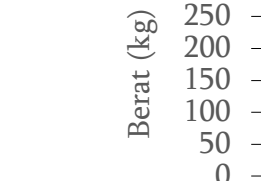 & 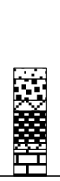 & 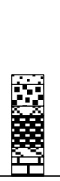 & 䦣 & 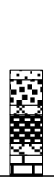 & 䕪 & 䕜 & 睃 & 8 & 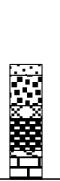 & 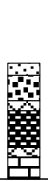 & 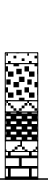 & 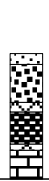 \\
\hline & 1 & 2 & 3 & 4 & 5 & 6 & 7 & 8 & 9 & 10 & 11 & 12 \\
\hline - Tamban $\left({ }^{*} \mathrm{~K} \_B\right)$ & 17 & 15 & 10 & 15 & 18 & 15 & 16 & 20 & 17 & 19 & 17 & 17 \\
\hline $\mathbf{8}$ Tamban & 33 & 34 & 40 & 40 & 45 & 35 & 45 & 56 & 48 & 40 & 58 & 60 \\
\hline \ Kembung $\left({ }^{*} \mathrm{~K} \_\mathrm{B}\right)$ & 17 & 15 & 17 & 15 & 17 & 20 & 21 & 18 & 20 & 16 & 18 & 15 \\
\hline Kembung & 50 & 50 & 43 & 45 & 50 & 60 & 50 & 40 & 50 & 57 & 45 & 50 \\
\hline$\checkmark \operatorname{Teri}\left({ }^{*} \mathrm{~K} \_\mathrm{B}\right)$ & 10 & 15 & 16 & 18 & 15 & 15 & 15 & 15 & 10 & 15 & 17 & 10 \\
\hline 巴Teri & 42 & 30 & 32 & 33 & 35 & 40 & 40 & 45 & 35 & 35 & 43 & 45 \\
\hline
\end{tabular}

Gambar 3 Total hasil tangkapan bagan dengan LED biru dan neon sebagai bagan kontrol LED biru (*K_B)

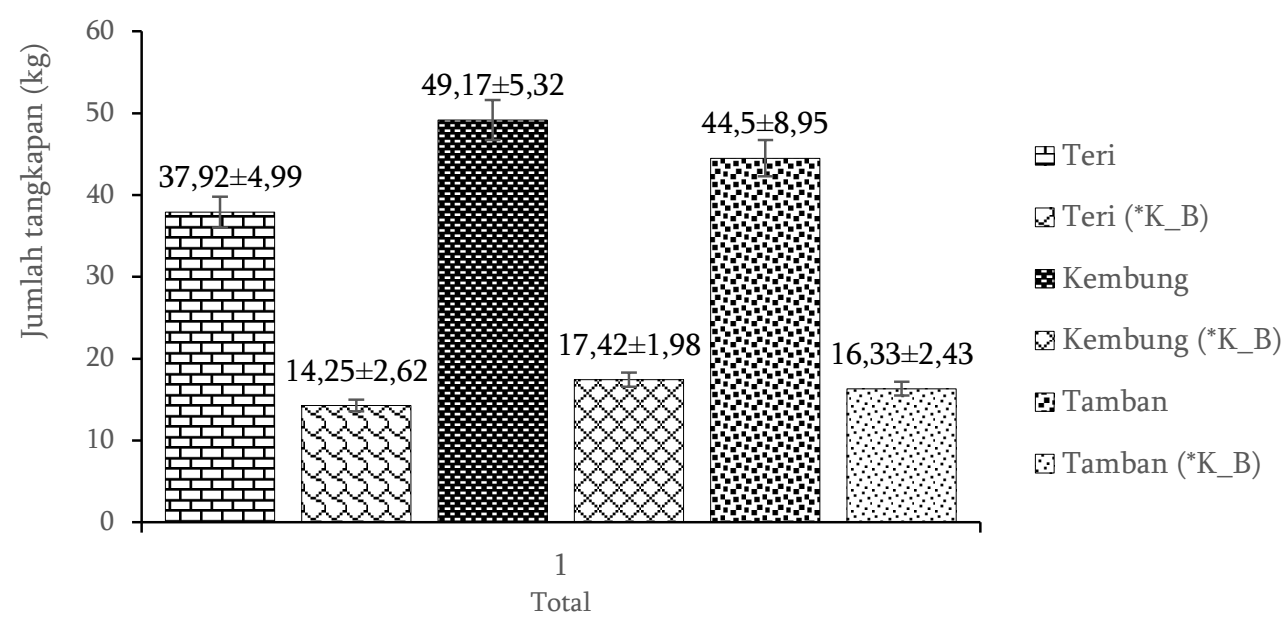

Gambar 4 Komposisi hasil tangkapan bagan perahu LED biru dan neon sebagai bagan kontrol

\section{LED merah}

Hasil tangkapan lampu celup LED merah mendapatkan dua spesies yang sama yaitu teri (Stolephorus devisi) dan kembung (Rastrelliger kanagurta) selama 12 kali operasi penangkapan. Total hasil tangkapan lampu celup LED merah sebesar $246 \mathrm{~kg}$ terdiri dari teri $224 \mathrm{~kg}$ dan kembung $22 \mathrm{~kg}$. Sedangkan total hasil tangkapan bagan kontrol sebesar $275 \mathrm{~kg}$ terdiri dari teri sebanyak 250 dan kembung $25 \mathrm{~kg}$. Hasil tangkapan bagan kontrol lebih tinggi dibandingkan hasil tangkapan pada perlakuan lampu celup LED merah. Penggunaan lampu celup LED merah mendapatkan hasil tangkapan lebih rendah dibandingkan dengan hasil tangkapan bagan kontrol. Komposisi hasil tangkapan bagan perahu dengan menggunakan lampu celup LED merah dan bagan kontrol disajikan pada Gambar 5 .

Total hasil tangkapan rata-rata bagan perahu dengan lampu celup LED merah untuk tangkapan teri sebesar $4.08 \pm 20.00 \mathrm{~kg}$ pada trip pertama, trip kedua $4.71 \pm 16.67 \mathrm{~kg}$, trip ketiga $5.79 \pm 21.33 \mathrm{~kg}$ dan trip keempat $2.36 \pm 16.67 \mathrm{~kg}$ dengan hasil tangkapan teri bagan kontrol trip pertama sebesar $4.08 \pm 20.00$ $\mathrm{kg}$, trip kedua $4.08 \pm 20.00 \mathrm{~kg}$, trip ketiga $4.71 \pm 21.67 \mathrm{~kg}$ dan trip keempat $2.36 \pm 21.67 \mathrm{~kg}$. Berdasarkan hasil analisis statistik menunjukkan tidak adanya perbedaan secara signifikan $(P>0.05)$ pada hasil tangkapan lampu celup LED merah dan bagan control. Seperti yang disajikan pada Gambar 6. 


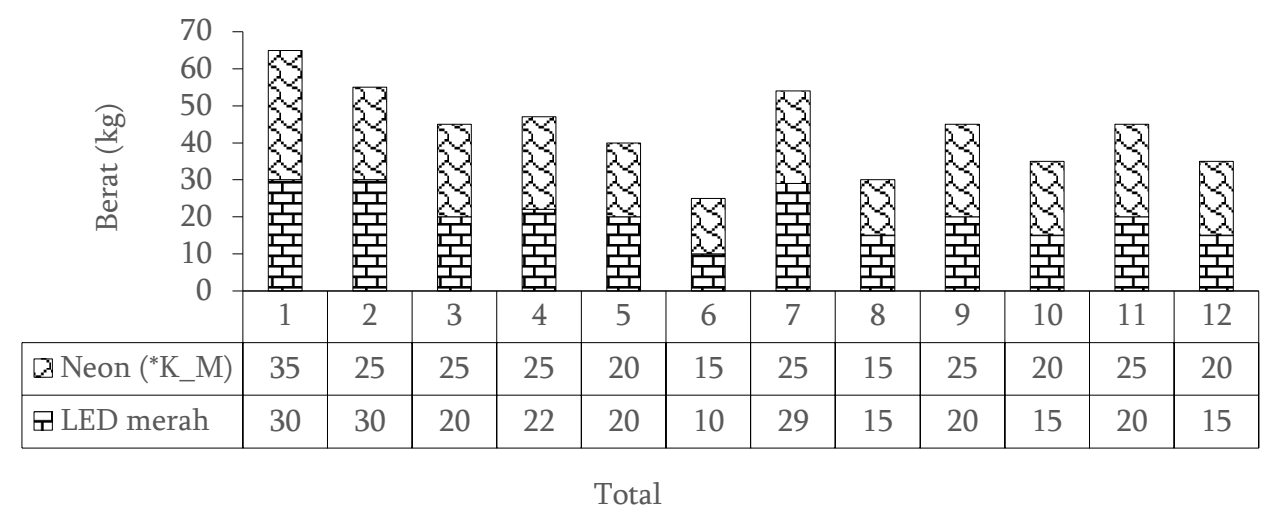

Gambar 5 Total hasil tangkapan bagan dengan LED merah dan neon sebagai bagan kontrol $\left({ }^{*} \mathrm{~K} \_\mathrm{M}\right)$

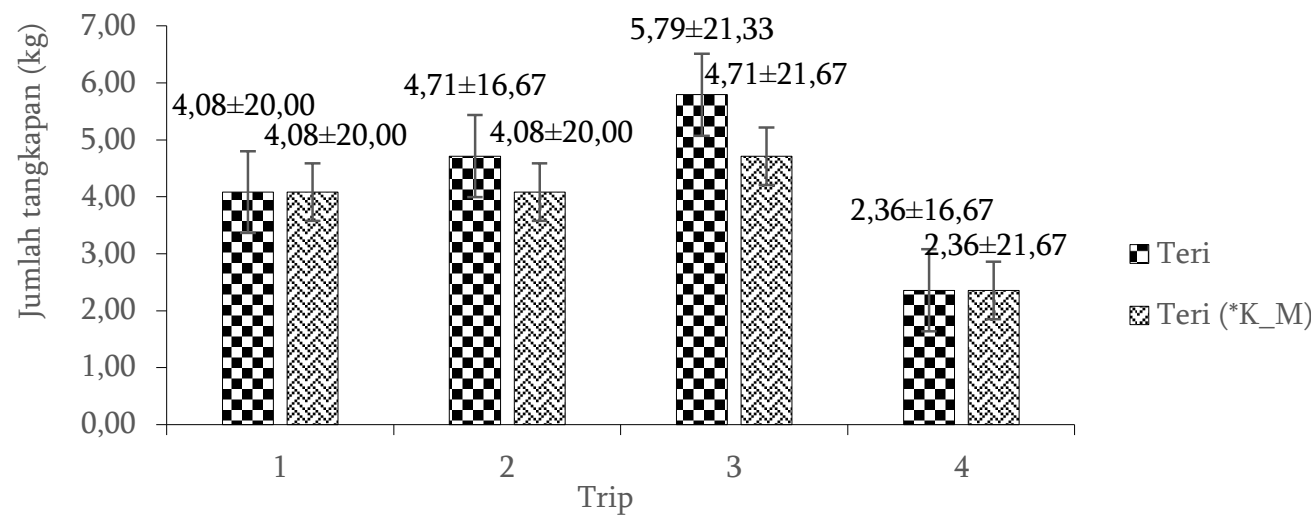

Gambar 6 Komposisi hasil tangkapan bagan LED merah dan neon sebagai bagan kontrol

Penggunaan lampu celup LED merah mendapatkan hasil tangkapan kembung dengan total tangkapan pada bagan perahu lampu celup LED merah sebesar $22 \mathrm{~kg}$ dan bagan kontrol $25 \mathrm{~kg}$. Ratarata hasil tangkapan lampu celup LED merah sebesar $2.05 \pm 7.33 \mathrm{~kg}$ dan bagan kontrol $2.36 \pm 8.33 \mathrm{~kg}$. Hasil analisis statistik tangkapan kembung lampu celup LED merah dengan bagan kontrol tidak terdapat perbedaan secara signifikan $(P>0.05)$ terhadap hasil tangkapan. Komposisi tangkapan disajikan pada Gambar 7.

Gambar 7 Komposisi hasil tangkapan bagan LED merah dan neon sebagai bagan kontrol

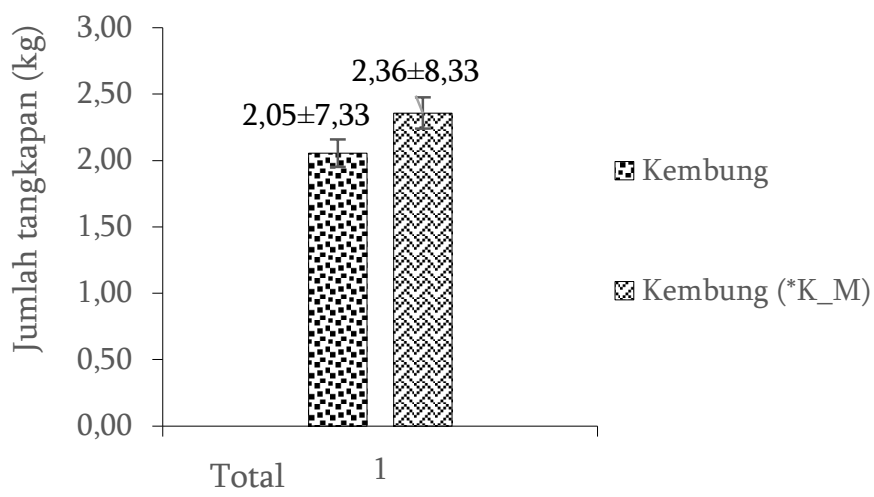




\section{LED kuning}

Hasil tangkapan lampu celup LED kuning dan bagan kontrol mendapatkan satu jenis yaitu ikan teri (Stolephorus devisi). Total hasil tangkapan selama 12 kali operasi penangkapan pada lampu celup LED kuning dengan jumlah total tangkapan teri sebesar $166 \mathrm{~kg}$ dan bagan kontrol sebesar $294 \mathrm{~kg}$. Perolehan hasil tangkapan bagan kontrol lebih tinggi dibandingkan dengan bagan lampu celup LED. Komposisi hasil tangkapan bagan perahu dengan lampu celup LED dan bagan kontrol disajikan pada Gambar 8.

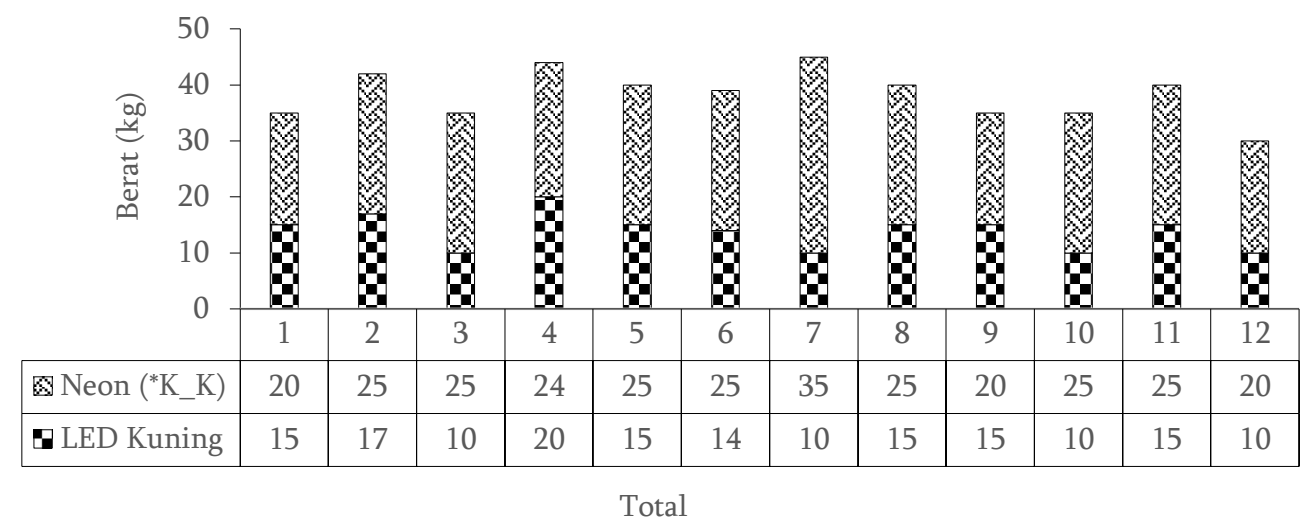

Gambar 8 Total hasil tangkapan bagan LED kuning dan neon sebagai bagan control LED kuning $\left({ }^{*} \mathrm{~K} \_\mathrm{K}\right)$

Total hasil tangkapan rata-rata bagan perahu dengan lampu celup LED kuning teri sebesar $2.94 \pm 14.00 \mathrm{~kg}$ pada trip pertama, trip kedua $2.62 \pm 16.33 \mathrm{~kg}$, trip ketiga $2.36 \pm 13.33 \mathrm{~kg}$ dan trip keempat $2.36 \pm 11.67 \mathrm{~kg}$. Hasil tangkapan teri pada bagan kontrol trip pertama sebesar $2.36 \pm 23.33 \mathrm{~kg}$, trip kedua $0.47 \pm 24.67 \mathrm{~kg}$, trip ketiga $6.24 \pm 26.67 \mathrm{~kg}$ dan trip keempat $2.36 \pm 23.33 \mathrm{~kg}$. Berdasarkan analisis uji statistik tidak terdapat perbedaan secara signifikan $(P>0.05)$ terhadap hasil tangkapan dengan menggunakan lampu celup LED kuning dan bagan kontrol. Seperti yang disajikan pada Gambar 9.

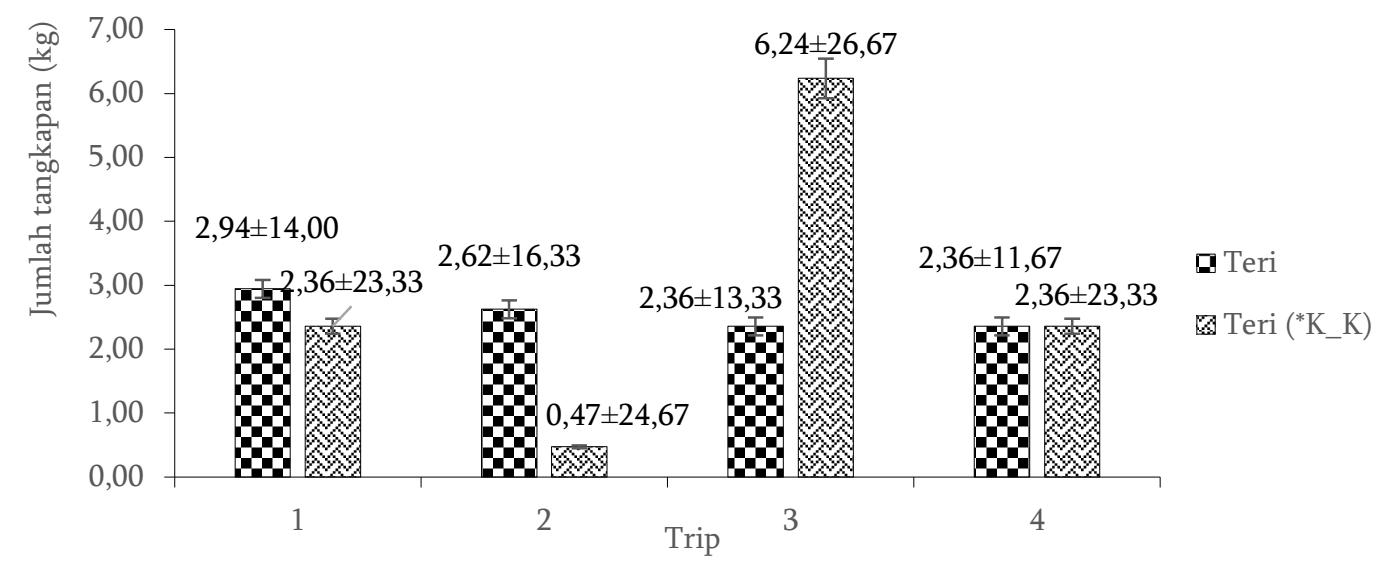

Gambar 9 Komposisi tangkapan LED kuning dan neon sebagai bagan kontrol

\section{Komposisi hasil tangkapan berdasarkan lampu}

Perbandingan hasil tangkapan menggunakan lampu petromaks putih, biru, kuning dan LED ultra bright putih serta LED super bright blue pada penelitian terdahulu dan hasil tangkapan lampu celup LED v.815 warna biru, merah dan kuning. Pada penelitian ini disajikan pada Tabel 1. 
Tabel 1 Komposisi hasil tangkapan berdasarkan warna lampu

\begin{tabular}{|c|c|c|}
\hline Jenis Lampu & Jenis tangkapan & Referensi \\
\hline $\begin{array}{l}\text { Petromaks } \\
\text { putih }\end{array}$ & $\begin{array}{l}\text { Teri } 70.39 \% \text {, cumi-cumi } 12.67 \% \text {, sotong } 1.41 \% \text {, udang pepe } \\
10.32 \% \text {, permato } 3.75 \% \text {, japuh } 0.94 \% \text {, petek } 0.23 \% \text {, } \\
\text { belanak } 0.09 \% \text {, julung-julung } 0 \% \text {, layur } 0.19 \% \text {. total } \\
\text { tangkapan } 106.55 \mathrm{~kg}\end{array}$ & \multirow{2}{*}{$\begin{array}{l}\text { Gustaman } \\
\text { et al. } 2012\end{array}$} \\
\hline $\begin{array}{l}\text { Petromaks } \\
\text { biru }\end{array}$ & $\begin{array}{l}\text { Teri } 32.81 \% \text {, cumi-cumi } 9.40 \% \text {, sotong } 1.86 \% \text {, udang pepe } \\
23.12 \% \text {, permato } 20.88 \% \text {, japuh } 5.97 \% \text {, petek } 5.97 \% \text {, } \\
\text { belanak } 0 \% \text {, julung-julung } 0 \% \text {, layur } 0 \% \text {. total tangkapan } \\
67.71 \mathrm{~kg}\end{array}$ & \\
\hline Petromaks & Teri $55.39 \%$, cumi-cumi $14.63 \%$, sotong $1.54 \%$, udang pepe & \\
\hline Kuning & $\begin{array}{l}26.00 \% \text {, permato } 1.54 \% \text {, japuh } 0.54 \% \text {, petek } 0.15 \% \text {, } \\
\text { belanak } 0.38 \% \text {, julung-julung } 0.20 \% \text {, layur } 0.15 \% \text {. total } \\
\text { tangkapan } 64.99 \mathrm{~kg}\end{array}$ & \\
\hline $\begin{array}{l}\text { LED ultra bright } \\
\text { putih }\end{array}$ & $\begin{array}{l}\text { Udang rebon } 24.69 \% \text {, pepetek } 23.26 \% \text {, teri nasi } 13.11 \% \text {, } \\
\text { teri hitam } 11.79 \% \text {, teri putih } 1.15 \% \text {, layur } 14.6 \% \text {, cumi- } \\
\text { cumi } 5.35 \% \text {, selar } 2.50 \% \text {, tembang } 1.56 \% \text {, bilis } 1.18 \% \text {, } \\
\text { kembung } 1.18 \% \text {. total tangkapan } 287.6 \mathrm{~kg}\end{array}$ & $\begin{array}{c}\text { Thenu } \\
2014\end{array}$ \\
\hline $\begin{array}{l}\text { LED super bright } \\
\text { blue }\end{array}$ & $\begin{array}{l}\text { Teri } 26.14 \% \text {, pepetek } 18.44 \% \text {, tembang } 14.90 \% \text {, kembung } \\
11.78 \% \text {, selar } 9.24 \% \text {, japuh } 7.54 \% \text {, layur } 6.62 \% \text { dan lain- } \\
\text { lain } 5.35 \% \text {. total tangkapan } 3779 \mathrm{~kg}\end{array}$ & $\begin{array}{l}\text { Taufiq } \\
2015\end{array}$ \\
\hline $\begin{array}{l}\text { LED celup } \\
\text { Biru }\end{array}$ & $\begin{array}{l}\text { Teri } 28.36 \% \text {, kembung } 37.60 \% \text {, tamban } 34.03 \% \text {. total } \\
\text { tangkapan } 1569 \mathrm{~kg}\end{array}$ & \\
\hline $\begin{array}{l}\text { LED celup merah } \\
\text { LED celup } \\
\text { kuning }\end{array}$ & $\begin{array}{l}\text { Teri } 91.06 \% \text {, kembung } 8.94 \% \text {. total tangkapan } 246 \mathrm{~kg} \\
\text { Teri } 100 \% \text {. total tangkapan } 166 \mathrm{~kg} \text {. }\end{array}$ & $\begin{array}{c}\text { Penelitian } \\
\text { ini }\end{array}$ \\
\hline
\end{tabular}

\section{PEMBAHASAN}

Hasil tangkapan bagan perahu dengan menggunakan lampu celup LED biru dan lampu neon kontrol mendapatkan tiga spesies yang sama terdiri dari teri (Stolephorus devisi), kembung (Rastrelliger kanagurta) dan tamban (Dussumieria elopsoides). Namun jumlah hasil tangkapan yang tertangkap berbeda pada setiap tripnya. Total hasil tangkapan bagan perahu lampu celup LED biru sebesar 73.27\% dan lampu neon kontrol 26.73\%. Perolehan tangkapan lampu celup LED biru lebih tinggi dibandingkan dengan menggunakan lampu neon kontrol. Penggunaan warna lampu yang berbeda dapat meningkatkan jenis hasil tangkapan hal ini di karenakan jenis ikan memiliki ketertarikan yang berbeda terhadap warna (Guntur et al. 2015).

Sebaran cahaya biru terabsorpsi dengan baik di dalam perairan, sehingga penetrasi kedalam air lebih jauh. Hal ini memungkinkan peluang yang lebih besar untuk ikan-ikan pada lokasi yang lebih jauh untuk merespons cahaya lampu untuk tertarik dan berkumpul pada cacthable area bagan perahu. Cahaya lampu warna biru memiliki panjang gelombang yang rendah tetapi spektrum cahaya yang lebih panjang sehingga dapat menerangi area penangkapan lebih luas (Sudirman dan Mallawa 2004). Faktor berkumpulnya ikan pada (catchable area) dapat disebabkan salah satunya karena pengaruh cahaya (Sudiman et al. 2004; Purbayanto et al. 2010; Simbolon 2010). Cahaya biru dapat menembus perairan sampai kedalaman lebih dari $10 \mathrm{~m}$, sementara cahaya merah akan terabsorpsi oleh air hanya 2-3 m (Gustaman et al. 2012).

Komposisi hasil tangkapan LED merah mendapatkan 2 spesies yang sama dengan bagan kontrol yaitu teri dan kembung. Total hasil tangkapan lampu celup LED merah sebesar 47.22\% dan lampu neon 
kontrol sebesar 52.78\%. Hal disebabkan cahaya lampu warna putih memiliki panjang gelombang lebih tinggi dibandingkan dengan lampu celup LED merah, sedangkan sebaran cahaya dari lampu celup LED merah tidak terabsorpsi sempurna dalam air. Ikan teri memiliki respons yang baik terhadap beberapa warna lampu, hal ini sesuai dengan hasil penelitian terdahulu (Tabel 1) dimana ikan teri tertangkap di bagan dengan warna lampu yang berbeda petromaks putih, biru, kuning (Gustaman et al, 2012), LED ultra bright putih (Thenu 2014), dan LED super bright blue (Taufiq 2015)

Hasil tangkapan lampu celup LED kuning mendapatkan satu spesies yaitu teri sebesar 36.09\% dengan lampu neon kontrol 63.91\%. Hasil analisis statistik menunjukan bahwa terdapat perbedaan di antara hasil tangkapan namun tidak berbeda nyata. Penggunaan lampu neon menunjukkan hasil lebih efektif dalam menarik perhatian ikan di sekitar bagan (Ta'ladin 2000). Penggunaan lampu neon juga dapat meningkatkan hasil tangkapan dibandingkan lampu menkuri dan pijar (Sudirman et al. 2013). Spektrum cahaya lampu neon warna putih lebih panjang, sehingga jangkauan sebaran cahaya lebih luas, Bila dibandingkan dengan lampu warna merah dan kuning, cahaya putih menghasilkan panjang gelombang lebih tinggi, sehingga jangkauan sebaran cahaya lebih luas.

Berdasarkan hasil penelitian tangkapan LED biru lebih tinggi baik jumlah dan spesiesnya. Hal ini didukung oleh Ayodhyoa (2001), cahaya warna biru memiliki gelombang cahaya pendek dan spektrum cahayanya lebih panjang sehingga jangkauan sebaran cahaya lebih luas dan intensitasnya lebih tinggi serta warna biru lebih banyak disukai oleh banyak jenis ikan. Pengggunaan lampu celup LED biru lebih efektif dan efisien serta berpeluang menggantikan lampu neon berdasarkan jumlah hasil tangkapan, daya tahan, konsumsi bahan bakar, dan biaya operasional yang dikeluarkan selama aktivitas penangkapan (Taufiq 2015).

Faktor yang menyebabkan ikan teri dominan tertangkap pada perlakuan lampu LED biru, merah dan kuning adalah musim penangkapan ikan di perairan ABDYA pada saat bulan Juli sampai September merupakan musim penangkapan ikan teri. Ikan teri termasuk kedalam jenis ikan pelagis kecil berkelompok (Schooling), hal ini sangat cocok dengan daerah penangkapan bagan perahu di perairan ABDYA yang dekat dengan pantai (Csirke 1988). Berkumpulnya ikan-ikan kecil seperti teri di sekitar bagan perahu akan memicu berkumpulnya ikan-ikan lain dengan ukuran lebih besar (Lee 2010) yang menyebabkan terjadinya rantai makanan antara ikan kecil dengan ikan predator seperti ikan kembung dan tamban yang berukuran lebih besar untuk mendapatkan makanan. Tingginya hasil tangkapan bagan perahu pada penelitian ini, juga disebabkan oleh kelimpahan ikan pada perairan tersebut. Kondisi perairan ADBYA masih tergolong dalam kondisi baik dan kaya akan zat hara yang terbawa dari daratan. Zat hara tersebut dimanfaatkan oleh fitoplankton yang selanjutnya dimanfaatkan oleh zooplankton, juvenile ikan ataupun ikan-ikan kecil yang merupakan makanan dari teri, kembung dan tamban (Tasywiruddin 1999). Ikan teri merupakan ikan pemakan plankton yang bersifat pelagik serta menyukai habitat perairan pesisir dan memiliki respon positif terhadap cahaya (Hutomo et al. 1987 dan Effendi 2005). Respons ikan terhadap cahaya tiap jenis ikan memiliki perbedaan seperti phototaxis positif, preferensi untuk intensitas cahaya optimum, investigatory reflex, untuk mengelompok dan mencari makan di bawah cahaya, serta disorientasi sebagai akibat kondisi buatan dari gradient intensitas cahaya di bawah air (Hakgeun et al. 2012).

Penangkapan menggunakan lampu telah dilakukan pada penelitian sebelumnya dengan menggunakan lampu petromaks pada operasi penangkapan bagan selama 3 hari operasi penangkapan dengan komposisi tangkapan warna putih sebanyak 10 spesies, warna biru sebanyak 10 spesies dan warna kuning sebanyak 10 spesies (Gustaman et al. 2012). Penangkapan dengan lampu LED ultra bright putih telah dilakukan selama 20 hari operasi penangkapan dengan komposisi tangkapan sebanyak 12 spesies (Thenu 2014). Penangkapan menggunakan LED super bright blue selama 20 hari operasi penangkapan dengan komposisi hasil tangkapan sebanyak 8 spesies (Taufiq 2015) dan hasil penelitian menggunakan lampu LED celup v.815 dengan warna biru, merah dan kuning selama 4 hari operasi penangkapan. LED biru dengan komposisi hasil tangkapan sebanyak 3 spesies, 4 hari operasi 
penangkapan LED merah dengan komposisi 2 spesies dan 4 hari operasi penangkapan LED kuning dengan tangkapan 1 spesies.

Berdasarkan komposisi hasil tangkapan lampu celup LED biru, merah dan kuning mendapatkan 3 spesies. Komposisi hasil tangkapan ini lebih sedikit dibandingkan lampu pertromaks dan LED ultra bright putih serta LED super bright blue. Hal tersebut dipengaruhi oleh operasi penangkapan di perairan ABDYA dilakukan pada saat musim barat sehingga spesies yang dominan tertangkap pada lampu celup LED biru, merah dan kuning terdiri dari 3 spesies yaitu teri, kembung dan tamban. Perairan yang berhadapan langsung dengan Samudera Hindia sangat dipengaruhi oleh kekuatan angin yang besar, terlebih pada musim barat. Selama musim ini ombak sangat besar disertai dengan angin dan hujan yang sangat lebat sehingga mempengaruhi operasi penangkapan serta hasil tangkapan. Beberapa faktor yang mempengaruhi hasil tangkapan di antaranya suhu, kecerahan, gelombang, topografi dasar perairan, posisi penempatan bagan, pengaruh musim dan pengaruh sinar bulan dan oseanografi (Baskoro et al. 2011 dan Yulianto et al.2014).

Berdasarkan komposisi hasil tangkapan lampu celup LED biru dengan lampu celup LED merah, lampu celup LED kuning dan lampu neon menunjukan perbedaan hasil tangkapan dan jenis tangkapan, dimana lampu LED biru lebih dominan menangkap 3 spesies terdiri dari teri, kembung dan tamban, lampu celup LED merah menangkap 2 spesies teri dan kembung sedangkan lampu celup LED kuning menangkap 1 spesies yaitu teri. Hasil analisis statistik tangkapan LED biru berbeda nyata dengan lampu celup LED merah dan lampu celup LED kuning. Pengunaan cahaya lampu warna celup warna biru lebih efektif dan efisien dalam operasi penangkapan pada bagan perahu untuk meningkatkan hasil tangkapan (Fujaya 2002). Melihat dari sifat cahaya lampu LED biru sangat sesuai digunakan pada operasi penangkapan ikan bagan perahu. Penggunaan cahaya lampu celup LED biru dapat meningkatkan hasil tangkapan dan sesuai digunakan pada operasi penangkapan ikan target tangkapan seperti spesies ikan teri, kembung dan tamban.

\section{KESIMPULAN DAN SARAN}

\section{Kesimpulan}

Komposisi hasil tangkapan lampu celup LED biru sebesar $1579 \mathrm{~kg}(38.38 \%)$ terdiri dari teri (Stolephorus devisi) sebanyak $455 \mathrm{~kg}$, kembung (Rastrelliger kanagurta) $590 \mathrm{~kg}$ dan tamban (Dussumieria elopsoides) $534 \mathrm{~kg}$ dengan bagan kontrol sebanyak $576 \mathrm{~kg}$ (23.61\%) terdiri dari teri 171 $\mathrm{kg}$, kembung $209 \mathrm{~kg}$ dan tamban $196 \mathrm{~kg}$. Lampu celup LED merah sebanyak $246 \mathrm{~kg}(7.58 \%)$ terdiri dari teri $224 \mathrm{~kg}$, kembung $22 \mathrm{~kg}$ dengan bagan kontrol $275 \mathrm{~kg}(14.34 \%)$ terdiri dari ikan teri $250 \mathrm{~kg}$, kembung $25 \mathrm{~kg}$ dan lampu celup LED kuning teri sebanyak $166 \mathrm{~kg}$ (4.04\%) dengan bagan kontrol 294 $\mathrm{kg}(12.05 \%)$. Penggunaan lampu celup LED biru secara signifikan meningkatkan hasil tangkapan sebesar $46.54 \%$ untuk tangkapan teri, kembung dan tamban dibandingkan lampu neon. Sedangkan hasil tangkapan lampu celup LED merah dan kuning tidak signifikan dalam meningkatkan hasil tangkapan dibandingkan lampu neon.

\section{Saran}

Penangkapan pada bagan perahu menggunakan lampu celup LED biru dapat meningkatkan hasil tangkapan. Namun perlu dilakukan penangkapan minimal satu musim menggunakan lampu celup LED biru, merah dan kuning untuk mengetahui jenis hasil tangkapan permusim di perairan Aceh Barat Daya (ABDYA).

\section{UCAPAN TERIMA KASIH}

Penelitian ini memperoleh biaya dari Lembaga Pengelola Dana Pendidikan (LPDP), melalui skim penerimaan Beasiswa (LPDP) tahun 2015. Oleh sebab itu kami ucapkan terima kasih yang sebesarbesarnya kepada LPDP atas pembiayaan penelitian hingga selesai. 


\section{DAFTAR PUSTAKA}

[DKP] Dinas Kelautan dan Perikanan. 2010. Fisheries \& Aquaculture Rehabilitation and Development Project, Aceh Province, Indonesia. Aceh. Blangpidie (ID): Dinas Kelautan dan Perikanan.

Ayodhyoa AU. 2001. Metode Penangkapan Ikan. Bogor (ID): Yayasan Dewi Sri.

Baskoro MS, Azbas TAM, Sudirman. 2011. Tingkah Laku Ikan: Hubungannya dengan Ilmu dan Teknologi Perikanan Tangkap. Bandung (ID): Lubuk Agung.

Effendi MI. 2005. Biologi Perikanan. Yogyakarta (ID): Yayasan Pustaka Nusantara.

Fujaya Y. 2002. Fisiologi Ikan. Dasar Pengembangan Teknologi Perikanan. Proyek Peningkatan Penelitian Pendidikan Tinggi Departemen Pendidikan Nasional.

Guntur, Fuad, Muntaha A. 2015. Pengaruh Intensitas Lampu Bawah Air Terhadap Hasil Tangkapan pada Bagan Tancap. Marine Fisheries. 6(2):195-202.

Gustaman G, Fauziyah, Insani. 2012. Efektifitas Perbedaan Warna Cahaya Lampu Terhadap Hasil Tangkapan Bagan Tancap di Perairan Sungsang Sumatera Selatan. J Maspari. 4(1): 92-102.

Gustaman. 2014. Efektifitas perbedaan warna cahaya lampu terhadap hasil tangkapan Bagan Tancap di Perairan Sungsang Sumatera Selatan. J Maspari 4(1): 92-102.

Hakgeun J, Seunghwan Y, Junghoon L, Young. 2012. The Retinular Responses of Common Squid Todarodes Pacificus for Energy Efficient Fishing Lamp Using LED. Elsevier Renewable Energy. 5(4):101-104.

Hutomo M, Marto AS, Djamali, Martosewojo S. 1987. Sumberdaya Ikan Teri di Indonesia. Jakarta (ID): Pusat Penelitian dan Pengembangan Oseanologi-Lembaga IImu Pengetahuan Indonesia.

Luchiari AC, Freire FAM. 2009. Effects of Environmental Colour on Growth of Nile Tilapia, Oreochromisniloticus (Linnaeus, 1758), Maintained Individually or in Broups. Application Ichthyology. 2(5):162-167.

Nadir M. 2000. Teknologi Light Fishing di Perairan Barru Selat Makassar: Sebaran Cahaya dan Hasil Tangkapan [tesis]. Bogor (ID): Institut Pertanian Bogor.

Nicol JAC. 1963. Some Aspects of Photoreception and Vision in Fishes. Adv Mar. Biol. 1:171-208.

Nybakken JW. 1988. Biologi Laut. Suatu Pendekatan Ekologi. Eidman HM, penerjemah. Jakarta (ID): PT. Gramedia.

Otanubun J, Patty W. 2010. Perbedaan Penggunaan Intensitas Cahaya Lampu Terhadap Hasil Tangkapan Bagan Apung di Perairan Selat Rosenberg Kabupaten Maluku Tenggara Kepulauan Kei. Solo (ID): Program Studi Pemanfaatan Sumberdaya Perikanan, Fakultas Perikanan dan Ilmu Kelautan, Universitas Surakarta. 6: 3-7.

Purbayanto A, Riyanto M, Fitri ADP. 2010. Fisiologi dan Tingkah Laku Ikan Pada Perikanan Tangkap. Bogor (ID): IPB Press.

Simbolon D, Sondita MFA, Amiruddin. 2010. Komposisi isi saluran pencernaan ikan teri (Stolephorus spp) di Perairan Barru, Selat Makassar. J Marine Indones Sci. 15(1):7-16.

Smith LS. 1982. Introduction Fish Physiology. London (UK): TFH Publication.

Subani W, Barus HR. 1989. Alat Penangkapan Ikan dan Udang Laut. J Penelitian Perikanan Laut. Jakarta (ID): No. 50 tahun 1988 (Edisi Khusus).

Sudirman H, Mallawa A. 2004. Teknik Penangkapan Ikan. Jakarta (ID): Rineka Cipta. 
Sudirman, Nessa MN. 2011. Perikanan Bagan dan Aspek Pengelolannya. Malang (ID): Universitas Muhammadiyah Malang (UMM) Press.

Sudirman. 2003. Analisis Tingkah Laku Ikan untuk Mewujudkan Teknologi Ramah Lingkungan dalam Proses Penangkapan pada Bagan Rambo [disertasi]. Bogor (ID): Institut Pertanian Bogor.

Ta'alidin Z. 2000. Pemanfaatan Lampu Listrik Dalam Upaya peningkatan Hasil Tangkapan Pada Bagan Apung Tradisional di Pelabuhan Ratu [tesis]. Bogor (ID): Institut Pertanian Bogor.

Tasywiruddin M. 1999. Sebaran Kelimpahan Cumi-cumi Berdasarkan Jumlah dan Posisi Lampu pada Operasi Penangkapan dengan Payang Oras di Perairan Selat Alas, Nusa Tenggara Barat [tesis]. Bogor (ID): Institut Pertanian Bogor.

Taufiq. 2015. Pengembangan Lampu Celup Led (super bright blue) untuk Perikanan Bagan Apung di Perairan Patek Kabupaten Aceh Jaya [tesis]. Bogor (ID): Institut Pertanian Bogor.

Thenu IM. 2014. Aplikasi Lampu Light Emitting Diode (LED) pada Pengoperasian Bagan Tancap [tesis]. Bogor (ID): Institut Pertanian Bogor.

Waloya T, Rodiahwati W, Widiyastuti LS, Purnama TP. 2010. Penggunaan Kincir Angin Savonius Sebagai Sumber Energi Lampu Celup Bawah Air (LACUBA) di Bagan Nelayan.

Won lea J. 2010. Pengaruh Periode Hari Bulan Terhadap Hasil Tangkapan dan Tingkatan pendapatan Nelayan Bagan Tancap di Kabupaten Serang [tesis]. Bogor (ID): Institut Pertanian Bogor.

Yulianto ES, Purbayanto A, Wisudo SH, Mawardi W. 2014. Lampu LED Bawah Air Sebagai Alat Bantu Pemikat Ikan pada Bagan Apung. Jurnal Teknologi Perikanan dan Kelautan. 5(1):83-93. 